\title{
Islamic Entrepreneurship in the Light of Maqasid Al-Shari'ah: A Critical Review
}

\author{
Farida Mohammed Shehu, Nor Hayati Binti Ahmad, Al-Hasan Al-Aidaros \\ University Utara Malaysia, Malaysia \\ fmshehu@yahoo.com
}

\begin{abstract}
The objectives of entrepreneurship in Islam are guided by the Maqasid Al-Shariah. However, there is a mismatch between Islamic entrepreneurship objectives and Maqasid Al-Shariah based on available literatures, which have not been critically investigated. This paper presents a critical review of the literature within the Islamic entrepreneurship objectives and Maqasid Al-Shariah framework. The exploratory study adopting content analysis to achieve its aim found that the existing literature covered both the Din and Mu'amalah based objectives of Islamic entrepreneurship. However, there is dearth of literature that integrates the connection between objectives of Islamic entrepreneurship and Maqasid Al-Shari'ah. It is therefore suggested that researchers should conduct more researches to examine the integration of Maqasid Al-Shariah in Islamic entrepreneurship, particularly in respect to decision making in handling entrepreneurship issues.
\end{abstract}

Keywords: Islamic entrepreneurship, business, Maqasid Al-Shari'ah

\section{Introduction}

The different views and issues surrounding entrepreneurship contributed to the development of researches and interest in the Islamic perspective of entrepreneurship. It is observed that issues affecting entrepreneurship are still addressed with little or no consideration to Islam. Islamic entrepreneurship however, is a more actual system which is based on the Al-Quran and Sunnah of the Prophet, Peace be Upon Him (PBUH). It is therefore imagined that the objectives surrounding Islamic entrepreneurship or doing business are supposed to be directed by Maqasid Al-Shari'ah. However, there is a mismatch between the objectives of Islamic entrepreneurship and Maqasid Al-Shari'ah. This paper is therefore a modest effort to fill this gap through highlighting the variations as well as consideration for integrating the two i.e. objectives of Islamic entrepreneurship and Maqasid Al-Shari'ah. The paper consists of five sections. Section one provides the brief background of the issue while section two describes the Islamic entrepreneurship in terms of definition, Islamic proof of entrepreneurship and objectives of Islamic entrepreneurship. Section three provides the definition and objectives of Maqasid Al-Shari'ah, while section four illustrates the integration between Maqasid Al-Shari'ah and objectives of Islamic entrepreneurship in a conceptual framework. Section five concludes the paper.

\section{Islamic Entrepreneurship}

Definition of Islamic Entrepreneurship: Islamic entrepreneurship is a composition of two concepts; Islam and entrepreneurship (Gümüsay, 2015). According to Zarabozo (2007) belief in Allah (SWT) is the foundation of the complete faith of Islam followed by all other Islamic beliefs and practices. The word Islam which has its origin from the Arabic word 'Salam' meaning peace entails submission to Allah (SWT) (Belt, 2002). The definition of Islam is clearly portrayed in a Hadith narrated by Abu Huraira; the prophet Peace Be Upon Him (PBUH) is asked by angel Jibril about faith, Islam and Ihsan (perfection) and Allah's Apostle replied, "faith is to believe in Allah, His angels, (the) meeting with Him, His Apostles, and to believe in Resurrection." Islam is "To worship Allah Alone and none else, to offer prayers perfectly to pay the compulsory charity (Zakkah) and to observe fasts during the month of Ramadan." Ihsan is "To worship Allah as if you see Him, and if you cannot achieve this state of devotion then you must consider that He is looking at you......." (Sahih Bukhari, Book 2, Hadith Number 47) Islamic entrepreneurship is therefore connected with belief and obedience to Allah (SWT) (Alserhan, 2011). 
Entrepreneurship is all about taking risk, creativity, innovation, and management of a firm and taking advantage of market opportunities (Abu-Saifan, 2012; Bula, 2012; Eroglu \& Picak, 2011). However, Binks and Vale (1990) provided a more dynamic outlook of entrepreneurship as a series of activities. Entrepreneurship is further seen as the examination of how, by whom and with what effects opportunities to create future goods and services are discovered, evaluated and exploited (Shane \& Venkataraman, 2000; Shane, 2003). Entrepreneurship is believed to compel economic growth and development in numerous countries (Hanafi, 2012). Entrepreneurship has been part of the Muslims life before the Prophet's era (Abdullah \& Mikail, 2013) and during the time of the Holy Prophet (PBUH) (Hamid, 2012). The Prophet (PBUH) himself was exposed to entrepreneurial activities since when he was a young boy (Abdullah \& Mikail, 2013) and he later engaged in trade with a successful business woman Khadija who later became his wife (Azmi, Basir, Muwazir, Hashim \& Mohamed, 2014). According to Rice (1999) when Muslim traders travelled to far-away lands, the dwellers of the lands use to be overwhelmed by the way they carry out their businesses and social relationships which made the dwellers curious about their belief and consequently led them to accept Islam. From the foregoing, Islamic entrepreneurship enforces firm conditions on opportunities, the process of exploiting the opportunities and the end objective of the entrepreneurial process (Kayed \& Hassan, 2013). The opportunity to be exploited must have a moral and ethical foundation, the means by which such opportunities are pursued and resources acquired and organized must be halal (permissible) and finally the ultimate goal must be to please Allah (SWT). Additionally, Muslim entrepreneurs need to realize that possessions, earnings and material goods and assets belong to Allah (SWT) and that man is only a trustee.

Islamic Proofs of Entrepreneurship: There are several proofs in the Al-Quran and Sunnah (teachings of the Prophet (PBUH)) that encourage entrepreneurship as well as indicate the benefits, permission and value of engaging in entrepreneurial activities. For instance, the indication of entrepreneurship is evident in Al-Quran (106: 1-4) where Allah (SWT) says:

(It is a great grace from Allah) for the protection of the Quraish, (And with all those Allah's grace and protections, We cause) the (Quraish) caravans to set forth safe in winter (to the south) and in summer (to the north without any fear), So let them worship (Allah) the Lord of this House (the Ka'bah in Makkah), (He) Who has fed them against hunger, and has made them safe from fear.

Additionally Allah (SWT) permits His servants both men and women to undertake any form of entrepreneurial activity on earth provided it does not violate the teachings of Islam. This is evident in $\mathrm{Al}$ Quran (62:10) where Allah (SWT) says:

"And when the prayer has been concluded, disperse within the land and seek from the bounty of Allah, and remember Allah often that you may succeed."

Again, Allah (SWT) says:

"It is He who made the earth tame for you - so walk among its slopes and eat of His provision - and to Him is the resurrection" (Al-Quran, 67:15).

In Al-Quran (28:77) Allah (SWT) further says:

But seek, through that which Allah has given you, the home of the Hereafter; and [yet], do not forget your share of the world. And do good as Allah has done good to you. And desire not corruption in the land. Indeed, Allah does not like corrupters.

Regarding trading as a form of entrepreneurial activity, "......Allah has permitted trade" (Al-Quran, 2:275). Even the longest verse in Al-Quran i.e. Al-Quran (2:282) presents indication of conduct of entrepreneurial activities saying: "O you, who have believed, when you contract a debt for a specified term, write it down..."

Furthermore, not less than 82 Quranic verses have linked Iman (faith) with good work (Al-Khayyat, 2008). For instance, Allah (SWT) says:

Whoever does righteous deeds, whether man or woman, while he/she is a believer, We shall most certainly give a good life, and will surely give them their reward [in the Hereafter] according to the best of what they used to do (Al-Quran, 16:97).

In addition, Allah (SWT) says: 
Anyone who does a bad deed shall be requited with no more than what is equal to it, whereas anyone, be it man or woman, who does what is right and is a believer shall enter paradise where they will all enjoy countless blessings (Al-Quran, 40:40).

Islamic entrepreneurship, variation in abilities and capabilities among human beings and justice can be further justified in the following verse of the Al-Quran where Allah (SWT) says:

And do not wish for that by which Allah has made some of you exceed others. For men is a share of what they have earned, and for women is a share of what they have earned. And ask Allah of his bounty. Indeed Allah is ever, of all things, Knowing (Al-Quran, 4:32).

The Prophet (PBUH) explained that nine out of the ten sources of income are attainable through engaging in business activities. Furthermore, Al-Suyuti mentioned a Hadith narrated on the authority of Rafi' that: The Holy Prophet (PBUH) was asked: "Which are the best forms of income generation?" He (PBUH) replied, "A man's labor and every legitimate sale" (Aziz, 2011). In Islam, importance is placed on entrepreneurship where generally, every Muslim entrepreneur is charged with the responsibility of making a living by pleasing Allah (SWT) through following the teachings of Islam (Hassan \& Hippler, 2014). To fulfill this responsibility, man is encouraged to do good work.

Table 1: Summary of Related Literatures on Din and Mu'amalah Based Objectives in Islamic Entrepreneurship

\begin{tabular}{|c|c|c|}
\hline Source & Din Based Objective & Mu'amalah Based Objective \\
\hline Gümüsay (2015) & To seek Allah's bounty & $\begin{array}{l}\text { Prohibition of Riba (interest), encouraging financial } \\
\text { partnership, prohibition of pork, alcohol or gambling, } \\
\text { hoarding, lying and false measurement, encouraging } \\
\text { trust and risk taking, purification of wealth by Zakkah. }\end{array}$ \\
\hline $\begin{array}{l}\text { Kayed and } \\
\text { Hassan (2013) }\end{array}$ & To please Allah (SWT) & Entrepreneurial activities must be halal, to gain profit. \\
\hline $\begin{array}{l}\text { Juma'h, Campus } \\
\text { and Abu-Mounes } \\
\text { (2011) }\end{array}$ & To gain the hereafter & $\begin{array}{l}\text { Prohibition of dealings with interest, encouraging } \\
\text { profit and loss sharing arrangements, and } \\
\text { differentiating between money and commodity, to } \\
\text { serve the society. }\end{array}$ \\
\hline Alserhan (2011) & Carrying out the will of God & $\begin{array}{l}\text { Condemnation of bribery, prohibition of fraud and } \\
\text { cheating, prohibition of interest, prohibition of certain } \\
\text { earnings, prohibition of hoarding, avoiding waste and } \\
\text { extravagance, payment of Zakkah, giving charity and } \\
\text { cleanliness. }\end{array}$ \\
\hline $\begin{array}{l}\text { Saripuddin } \\
(2015)\end{array}$ & $\begin{array}{l}\text { Sincere intention (to gain } \\
\text { the pleasure of Allah in } \\
\text { every aspect of life) }\end{array}$ & $\begin{array}{l}\text { Not to be involved in usurious practices, avoiding scam, } \\
\text { justice and trust. }\end{array}$ \\
\hline $\begin{array}{l}\text { Abdullah and } \\
\text { Mikail (2013) }\end{array}$ & $\begin{array}{l}\text { Entrepreneurship is aimed } \\
\text { to achieve the blessings and } \\
\text { glory of Allah (SWT) }\end{array}$ & $\begin{array}{l}\text { Earn a living from halal sources, spend earnings wisely, } \\
\text { effective management of resources, prohibition of } \\
\text { fraud, to act justly. }\end{array}$ \\
\hline $\begin{array}{lr}\text { Kayed } & \text { and } \\
\text { Hassan } & (2010)\end{array}$ & $\begin{array}{l}\text { Intended to please the } \\
\text { Almighty }\end{array}$ & $\begin{array}{l}\text { To generate halal income/profit, to meet financial } \\
\text { obligations and to contribute to the falah (well-being) } \\
\text { of the Muslim ummah (nation) in this life and hereafter. }\end{array}$ \\
\hline
\end{tabular}

Objectives of Islamic Entrepreneurship: The objectives of Islamic entrepreneurship are derived from and guided by the Al-Quran and Sunnah. As such the objectives of Islamic entrepreneurship are not far from the principles of Islam with regards to conducting entrepreneurial activities or businesses. The principles of Islam therefore direct the objectives of Islamic entrepreneurship. Different scholars have presented the objectives of Islamic entrepreneurship differently. For the purpose of this paper, the selected literatures will be viewed from two broad objectives. The Din objective which entails the objective that focuses on the relationship between Allah (SWT) and man and the Mu'amalah objectives which constitute the relationship between man and mankind as well as man and the environment. As indicated in Table 1, the Din objective entails more of undertaking the business to please Allah (SWT). Din from the literature is the basic objective 
of entrepreneurship in Islam (Gümüsay, 2015; Kayed \& Hassan, 2013; Alserhan, 2011; Saripuddin, 2015; Abdullah \& Mikail, 2013; Kayed \& Hassan, 2010). The Din based objective forms the foundation and the faith aspect of Islamic entrepreneurship which facilitates the achievement of the Mu'amalah objectives. The Mu'amalah based objectives bring about peaceful co-existence between man and other living thing without which there will be chaos on earth. From the literatures reviewed it is indicated that the Din based objectives are foremost followed by Mu'amalah based objectives, and that both Din based and Mu'amalah based objectives are considered in all the literatures. Table 2 provides the critical review of the literature addressing the objectives of Islamic entrepreneurship and the integration of the objectives of Islamic entrepreneurship and Maqasid Al-Shari'ah. What surfaced from the review is that; there is dearth of literature on Islamic entrepreneurship as strongly tied to Maqasid Al-Shari'ah as only one study indicated such a link (Abdullah \& Mikail, 2013).

Table 2: Summary of Findings from Critical Review

\begin{tabular}{|c|c|c|}
\hline Source & $\begin{array}{lll}\text { Addressed } & \text { Objectives } & \text { of } \\
\text { Islamic Entrepreneurship } & \end{array}$ & $\begin{array}{l}\text { Addressed the Integration of Objectives } \\
\text { of Islamic Entrepreneurship and Maqasid } \\
\text { Al-Shari'ah }\end{array}$ \\
\hline Gümüsay (2015) & $\sqrt{ }$ & $x$ \\
\hline $\begin{array}{l}\text { Kayed and Hassan } \\
(2013)\end{array}$ & $\sqrt{ }$ & $x$ \\
\hline $\begin{array}{l}\text { Juma'h, Campus and } \\
\text { Abu-Mounes (2011) }\end{array}$ & $\sqrt{ }$ & $x$ \\
\hline Alserhan (2011). & $\sqrt{ }$ & $x$ \\
\hline Saripuddin (2015) & $\sqrt{ }$ & $x$ \\
\hline $\begin{array}{l}\text { Abdullah and Mikail } \\
\text { (2013) }\end{array}$ & $\sqrt{ }$ & $\sqrt{ }$ \\
\hline $\begin{array}{l}\text { Kayed and Hassan } \\
(2010)\end{array}$ & $\sqrt{ }$ & $x$ \\
\hline
\end{tabular}

$\sqrt{ }=$ Yes

$x=$ No

\section{Maqasid Al-Shari`ah}

Definition of Maqasid Al-Shari ah: Maqasid involves a class of divine objectives and moral thoughts upon which Shari'ah is based, such as, fairness, self-confidence, freedom, facilitation, and social cooperation (Baqutayan, 2012). According to Mohammad and Shahwan (2013), a life without objectives and direction is futile. Shari ah is defined as an ordained way which covers all aspects of life such as financial and commercial among others with its unchanging bearings as well as its major means of adjusting to change (Sardar, 2003). The reference to Shari'ah as an ordained way is evident in Al-Quran (45:18), where Allah (SWT) says:

"Then we put you, (O Muhammad), on an ordained way concerning the matter (of religion); so follow it and do not follow the inclinations of those who do not know".

Maqasid Al-Shari'ah entails the essence of human existence without the fulfillment of which life will be lived in confusion and commotion (Mohammad \& Shahwan, 2013). To Al-Ghazali the Maqasid Al-Shari'ah is aimed at promoting well-being of humanity, which lies in protecting and safeguarding their faith (din), their human self ( $n a f s$ ), their intellect ('aql), their posterity (nasl) and their wealth (mal) (Dusuki \& Abdullah, 2007). Whatever ensures and safeguards these five Maqasid serves public interest and is desirable (Chapra, 2000). Al-Shatibi further approves that the list and sequence by Al-Ghazali are preferred in terms of their harmony with the core of Shari'ah (Nyazee, 1999). Maqasid Al-Shari'ah is therefore repeatedly translated as the goals or objectives of Shari'ah (Bedoui \& Mansour, 2014). The primary aim of Maqasid Al-Shari'ah is to serve the interest of the people, shield them from mischief and destruction and promote cooperation and mutual support (Dusuki \& Bouheraoua, 2011). 
Moreover, Maqasid Al-Shari'ah is universal as clearly indicated in the Al-Quran (34:28), where Allah (SWT) says:

"And We have not sent you except comprehensively to mankind as a bringer of good tidings and a warner. But most of the people do not know"

Again, in Al-Quran (7:158) Allah (SWT) says:

Say, [0 Muhammad], "O mankind, indeed I am the Messenger of Allah to you all........".

Furthermore, it is inclusive (encompasses all acts of responsibilities to Allah (SWT) and responsibilities regarding fellow humans and the environment which rests on solid Quranic foundation. This is also justified in Al-Quran (16:89) where Allah (SWT) says:

".........And we have sent down to you the Book as clarification for all things and as guidance and mercy and good tidings for the Muslims."

\section{The Objectives of Islamic Entrepreneurship: Integrating the Link with Maqasid Al-Shari'ah}

Figure 1 illustrates the integration between the objectives of Islamic entrepreneurship and Maqasid AlShari'ah. The essentials of Maqasid Al-Shari'ah are preservation of faith, life, intellect, progeny and wealth (Dusuki \& Abdullah, 2007). When any of these essentials is not met, then human life will be in chaos (Mohammad \& Shahwan, 2013). This implies that when Maqasid Al-Shari'ah is embedded in entrepreneurship, the society as a whole will prosper. Importantly, any decision, product or service that violates any of the objectives is against the teachings of Islam and must not be accepted and adopted. Islamic entrepreneurship is regarded as part of Ibadah (worship) to earn the blessings and glory of Allah (SWT) (Abdullah and Mikail, 2013). This ideally should be the intention of every Muslim entrepreneur. Moreover, undertaking the business only to please Allah (SWT) is accompanied by other objectives which will make it possible for the entrepreneur to meet his needs, support the family and pay Zakkah among others. By so doing, the faith of the entrepreneur will be protected because the expectation is that when an entrepreneur desires to please Allah in whatever he does then he will abide by the right practices laid down by Islam. As such, the entrepreneurial activity must be Shari'ah compliant i.e. they must abide by the rulings of the $\mathrm{Al}$ Quran and Sunnah of the Prophet (PBUH) to earn the blessings from Allah (SWT). When the whole objectives (Din and Mu'amalah) of Islamic entrepreneurship are realized, then the entrepreneur will have higher probability being successful.

Hence, in conducting the business, the entrepreneur must not deal with Riba (interest) in whatever magnitude (high and low) and condition (temptation and hardship) as prohibited in Islam. According to Siddiqi (2004), there are 12 verses in Al-Quran referring to Riba and the word 'Riba' occurs three times in one verse (Al-Quran, 2:275), one time each from several other verses (Al-Quran, 2:276, 2:278, 3:130, 4:161, 30:39). The Al-Quran, for example, contains the following verse condemning interest:

"O you who have believed do not consume interest, doubled and multiplied, but fear Allah that you may be successful" (Al-Quran, 3:130).

The Prophet (PBUH) reported by Jabir; cursed the receiver and the payer of interest, and the one who records it (the contract) and the two witnesses to the transaction and said, "They are all alike in guilt" (Sahih Muslim, Book 10, Hadith Number 3881).

When the objective of not engaging in Riba is fulfilled, there will be harmony in societies. In addition, exploitation, subjugation, oppression and inequality among mankind will be eliminated (Saripuddin, 2015).

Figure one also highlight that to further foster a decent relationship between the entrepreneur and fellow men, the entrepreneur is not expected to engage in the production of prohibited goods and services that will affect people's lives negatively (causing diseases and death) such as pork, intoxicants, clubs and casinos. This will enhance the preservation of lives, which is very important. The prohibition of production of pork for example is evident in not less than four verses of the Al-Quran; 2:173, 5:3, 6:145 and 16:115. For example, in Al-Quran (6:115) Allah (SWT) says:

He has only forbidden to you dead animals, blood, the flesh of swine, and that which has been dedicated to other than Allah. But whoever is forced [by necessity], neither desiring [it] nor transgressing [its limit] - then indeed, Allah is Forgiving and Merciful.

For others like alcohol/intoxicants and gambling, Allah (SWT) in Al-Quran (5:91) says: 
"Satan only wants to cause between you animosity and hatred through intoxicants and gambling and to avert you from the remembrance of Allah and from prayer. So will you not desist?"

Apart from affecting lives, things like alcohol/intoxicants and gambling affect faith because they divert the attention of people from praying and fasting among others. Allah (SWT) encourages that they should be avoided to become successful.

"O you who have believed, indeed, intoxicants, gambling, [sacrificing on] stone alters [to other than Allah], and divining arrows are but defilement from the work of Satan, so avoid it that you may be successful" (AlQuran, 5:90).

With regard to the preservation of intellect, this is closely linked to the protection of lives particularly to the prohibition of intoxicants. However, the focus is the preservation of the thinking faculty. As such, the entrepreneur should not produce, distribute and encourage the consumption of intoxicants for example alcohol, wine, beer and home-made alcoholic brews. Allah (SWT) says:

"They ask you about wine and gambling. Say, "In them is great sin and [yet, some] benefit for people. But their sin is greater than their benefit....." (Al-Quran, 2:219). A society with intellectually sound population is expected to be successful and achieve overall growth and development.

For the preservation of posterity, it is important that the entrepreneurial activity from discovery of the opportunity to the production of the product or service should create balance and ensure effective management of resources (Abdullah \& Mikail, 2013). Allah (SWT) in Al-Quran (55:7) says:

"And the heaven He raised and imposed the balance".

Production of goods and services that are hazardous to the environment is not accepted in the Maqasid AlShari'ah framework. Otherwise, future generation will be jeopardized. In this regard, even the trees and animals have to be protected. The Prophet (PBUH) said: "If any Muslim plants a tree or sows a field, and a human, bird or animal eats from it, it shall be reckoned as charity from him" (Saheeh Al-Bukhari, Book 39, Hadith 513).

Furthermore, all of the resources upon which life depends, have been created by Allah (SWT) as a trust in our care. He has ordained sustenance for all people and for all living things. Allah (SWT) says:

"And He placed on the earth firmly set mountains over its surface, and He blessed it and determined therein its [creatures'] sustenance in four days without distinction - for [the information] of those who ask." (AlQuran, 41:10).

Therefore, the entrepreneur should not abuse and misuse the natural resources as each generation is entitled to benefit from them.

The last objective within the Maqasid Al-Shari'ah framework is preservation of wealth and it entails that the entrepreneur should utilize any product or service that encourages legitimate trade, profit and loss sharing, righteous corporation, fosters justice and trust. Such services will prevent exploitation, injustice and unequal distribution of wealth. In support of legitimate trade, Islamic financial contracts such as Murabaha financing is accepted within the framework and should be used as an alternative to interest-related earnings by the entrepreneur to meet the financial needs of the enterprise. This is evident in Al-Quran where Allah (SWT) says: "Allah has permitted trade and forbidden usury" (Al-Quran, 2:275). Furthermore, Al-Suyuti mentioned a Hadith narrated on the authority of Rafi' that: The Holy Prophet (PBUH) was asked: "Which are the best forms of income generation?" He (PBUH) replied, "A man's labor and every legitimate sale" (Aziz, 2011). Musharakah and Mudharabah arrangements are also acceptable within the Maqasid Al-Shari'ah framework since they are in accordance with the principle of profit and loss sharing. This is established by Hallaq (2004), who upholds that contractual and commercial transactions are blessed and promoted in Islam as these protect, help and increase wealth. Furthermore, for Allah to preserve ones' wealth, the business must not be fraudulent in any way or form. Allah (SWT) has cursed those that cheat in businesses. In Al-Quran (83:1-3) Allah (SWT) says:

"Woe to those who give less [than due], who, when they take a measure from people, take in full. But if they give by measure or by weight to them, they cause loss."

To further preserve wealth, Islam encourages reasonable spending as such; entrepreneurs should avoid wasteful spending and extravagance. Such encouragement is evident in Al-Quran (25:67): "And [they are] 
those who, when they spend, do so not excessively or sparingly but are ever, between that, [justly] moderate". Excess goods or earnings can be channeled into charity because "Allah (SWT) destroys interest and gives increase for charities" (Al-Quran 2:276). "And whatever you give for interest to increase within the wealth of people will not increase with Allah. But what you give in Zakkah, desiring the countenance of Allah - those are the multipliers" (Al-Quran, 30:39). Giving alms ensure equitable distribution of income by narrowing the mismatch between the rich and poor and meeting the needs of the society as a whole. For wealth to be further preserved there is the need for the entrepreneur to be just by treating customers equally on a fair basis. Justice is a commandment of Allah (SWT); "Indeed, Allah orders justice and good conduct and giving to relatives and forbids immorality and bad conduct and oppression....."(Al-Quran, 16:90). Additionally, Islam considers profit motive of entrepreneurship to be halal and moral so far as it is free of interest, hoarding, bribery, speculation, monopoly, exploitation, and it is not the ultimate goal (Kayed \& Hassan, 2010).

Importantly, each Mu'amalah based objectives are meant to serve the Din based objective. This is as proposed in the categorization of Maqasid Al-Sharia by Imam Ghazali into two major divisions; the deeni (related to deen: protection of faith) and the dunyawi (related to this material world: protection of life, posterity, intellect and wealth), where each dunyawi purpose is meant to serve the single deeni purpose (Al-Mubarak \& Osmani, 2010).

Fig 1: Conceptual Integration between Maqasid Al-Shariah Framework and Objectives of Islamic Entrepreneurship

Al-Ghazali's Theory
Entrepreneurship

Objectives of Islamic

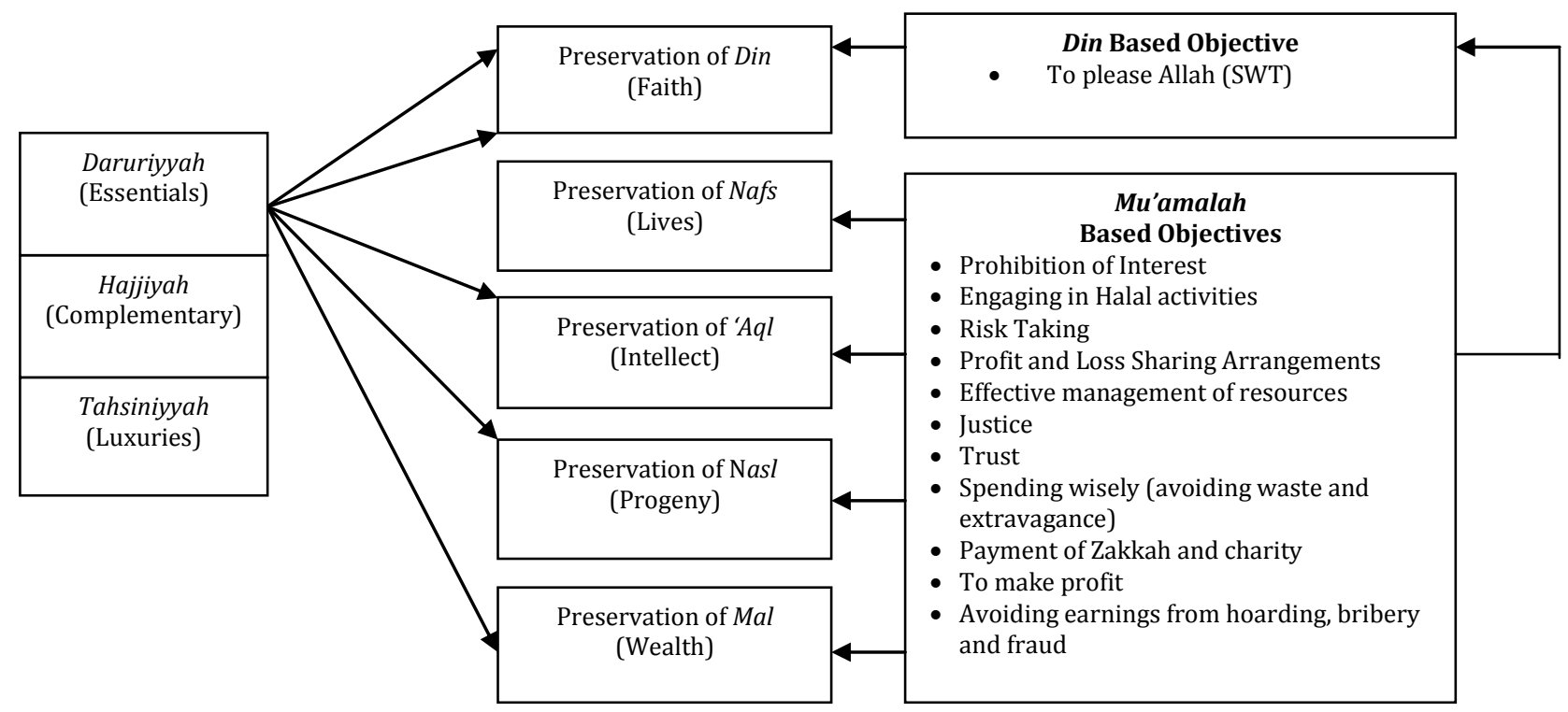

\section{Conclusion}

This paper aims to realign the mismatch between the Islamic entrepreneurship objectives and that of Maqasid Al-Shari'ah, a gap in the present business practice. Through critical review of related literatures, it is found that there is a strong conceptual link between objectives of Islamic entrepreneurship and Maqasid AlShari'ah. It could be further implied that most of the past studies did not demonstrate the connection between Islamic entrepreneurship and the Maqasid. The authors offer new contribution by providing a new conceptual framework integrating the Islamic entrepreneurship objectives and Maqasid Al-Shari'ah particularly within Al-Ghazali's theory of Maqasid Shari'ah. It is therefore suggested that future research should empirically investigate the proposed conceptual framework to enhance the sustainability of Islamic entrepreneurship success. 


\section{References}

Abu-Saifan, S. (2012). Social entrepreneurship: definition and boundaries. Technology Innovation Management Review, 2(2), 22-27.

Abdullah, S. \& Mikail, S. A. (2013). Entrepreneurship and Islam: An expository study on characteristics of Muslim entrepreneur. Proceeding of the 5th Islamic Economics System Conference: Sustainable Development Through The Islamic Economics System, Faculty Economics And Muamalat, Universiti Sains Islam Malaysia, Kuala Lumpur.

Al-Mubarak, T. \& Osmani, N. M. (2010). Applications of Maqasid al-Shari'ah and Maslahah in Islamic banking practices: An analysis. Paper presented at the International Seminar on Islamic Finance. (pp.1-17). Kochi, India. Retrieved 20th, 2015, from http://irep.iium.edu.my/4251/1/Applications_of_Maqasid_Shari\%60ah.pdf

Al-Quran, Arabic Text with corresponding English Meanings. (1997). Translated by Saheeh International. Riyadh: Abdulqasim Publishing House.

Alserhan, B. A. (2011). The principles of Islamic marketing. Gower Publishing, Ltd.

Aziz, A. \& Faizal, A. (2011). Islamic finance within trading framework: The way to legitimate profit. Munich Personal RePEc Archive, 47769, 1-29.

Azmi, I. A. G., Basir, A., Muwazir, M. R., Hashim, R. C. \& Mohamed, H. A. (2014). Motivation of Muslim women entrepreneurs in Malaysian SMEs. Paper presented at the 4th International Conference on Management, (pp. 1-11). Bali, Indonesia.

Baqutayan, S. (2012). The innovation of human nature in Islam. International Journal of Social Sciences and Education, 2(1), 162-173.

Bedoui, H. E. \& Mansour, W. (2015). Performance and maqasid al-shari'ah's pentagon-shaped ethical measurement. Science and Engineering Ethics, 21(3), 555-576.

Belt, D. (2002). The world of Islam. National Geographic. Retrieved 25 http://ngm.nationalgeographic.com/ngm/data/2002/01/01/html/ft_20020101.5.html.

Binks, M. \& Vale, P. (1990). Entrepreneurship and Economic Change. New York: McGraw-Hill.

Bula, O. H. (2012). Evolution and theories of entrepreneurship: A critical review on the Kenyan perspective. International Journal of Business and Commerce, 1(11), 81-96.

Chapra, M. U. (2000). The Future of Economics: An Islamic Perspective. Leicester: The Islamic Foundation.

Dusuki, A. W. \& Abdullah, N. I. (2007). Maqasid al-shari'ah, Maslahah and corporate social responsibility. The American Journal of Islamic Social Sciences, 24(1), 25-45.

Dusuki, A. W. \& Bouheraoua, S. (2011). The framework of Maqasid al-Shari'ah and its implication for Islamic finance. Islam and Civilisational Renewal, 2(2), 316-336.

Eroglu, O. \& Picak, M. (2011). Entrepreneurship, national culture and Turkey. International Journal of Business and Social Science, 2(16), 146-151.

Gümüsay, A. A. (2015). Entrepreneurship from an Islamic perspective. Journal of Business Ethics, 130(1), 199208.

Hadith. Retrieved from: http://www.searchtruth.com

Hallaq, W. B. (2004). A History of Islamic Legal Theories: An Introduction to Sunni Usul al-Fiqh. United Kingdom: Cambridge University Press.

Hamid, E. S. (2012). Initiating Islamic Entrepreneurship among Muslim Communities. Proceedings of the International Conference on Islamic Leadership-2, (pp. 23-36). Indonesia, University of Indonesia.

Hanafi, N. (2012). Business performance of women-owned SMEs in Malaysia: Learning and entrepreneurial orientations and the mediating roles of competitive advantage. Unpublished Doctoral Dissertation, Universiti Utara Malaysia.

Hassan, M. K. \& Hippler III, W. J. (2014). Entrepreneurship and Islam: An Overview. Econ Journal Watch, 11(2), 170-178.

Juma'h, A. H., Campus, M. \& Abu-Mounes, R. N. (2011). An introduction to the Islamic perspectives of conducting business. Revista Empresarial Inter Metro / Inter Metro Business Journal, 7(1), 58-68.

Kayed R. N. \& Hassan, M. K. (2010). Islamic entrepreneurship: A case study of Saudi Arabia. Journal of Developmental Entrepreneurship, 15(4), 379-413.

Kayed, R. N. \& Hassan, M. K. (2013). Islamic entrepreneurship. London: Routledge.

Mohammad, M. O. \& Shahwan, S. (2013). The objective of Islamic economic and Islamic banking in light of Maqasid Al-Shariah: A critical review. Middle-East Journal of Scientific Research, 13, 75-84. 
Rice, G. (1999). Islamic ethics and the implications for business. Journal of Business Ethics, 18(4), 345-358.

Saripuddin, S. O. Z. M. (2015). Concept of business ethics in Islam - approach to the entrepreneur. Journal of Asian Business Strategy, 5(1), 13-18.

Shane, S. (2003). A General Theory of Entrepreneurship: The Individual-Opportunity Nexus. UK: Edward Elgar.

Shane, S. \& Venkataraman, S. (2000). The promise of entrepreneurship as a field of research. Academy of management review, 25(1), 217-226.

Zarabozo, J. (2007). What is Islam? Riyadh: Ministry of Islamic Affairs Endowments, Da'wah, and Guidance, Saudi Arabia. 